\title{
Comparison of $\mathrm{FT}_{3}, \mathrm{FT}_{4}$ and $\mathrm{TSH}$ levels in Pregnant Women in Dehradun, India
}

\author{
Vishal Kumar Deshwal ${ }^{1 *}$, Abhay Yadav ${ }^{2}$ and J.B. Gogoi ${ }^{3}$ \\ ${ }^{1}$ Dept. of Microbiology; ${ }^{2}$ Dept. of Medical Laboratory Technology, Doon (P.G.) Paramedical College, Dehradun-248001, India; \\ ${ }^{3}$ Dept. of Biochemistry, Veer Chandra Singh Garhwali Government Institute of Medical Science and Research, \\ Srinagar, Pauri Garhwal, Uttrakhand \\ vishal_deshwal@rediffmail.com*; +919897538555
}

\begin{abstract}
This study was carried out to investigate thyroid hormone TSH (Thyroid-stimulating Hormone), Free $\mathrm{T}_{3}$ $\left(\mathrm{FT}_{3}\right)$ and Free $\mathrm{T}_{4}\left(\mathrm{FT}_{4}\right)$ status in pregnant women at Dehradun, Uttarakhand (India). Only 100 healthy pregnant women were selected for the present study. TSH, Free $T_{3}\left(F_{3}\right)$ and Free $T_{4}\left(F_{4}\right)$ were quantitatively analyzed. $\mathrm{FT}_{3}, \mathrm{FT}_{4}$ and $\mathrm{TSH}$ in the first trimester of pregnant showed $07.40 \pm 1.26 \mathrm{pmol} / \mathrm{L}$, $14.20 \pm 1.75 \mathrm{pmol} / \mathrm{L}$ and $01.41 \pm 0.93 \mathrm{mIU} / \mathrm{L}$ respectively. Second trimester of pregnant $\mathrm{FT}_{3}, \mathrm{FT}_{4}$ and $\mathrm{TSH}$ was $04.05 \pm 1.13 \mathrm{pmol} / \mathrm{L}, 12.02 \pm 2.01 \mathrm{pmol} / \mathrm{L}$ and $01.56 \pm 0.86 \mathrm{mIU} / \mathrm{L}$ and third trimester of pregnant $\mathrm{FT}_{3}, \mathrm{FT}_{4}$ and TSH was $02.92 \pm 0.93 \mathrm{pmol} / \mathrm{L}, 07.96 \pm 1.78 \mathrm{pmol} / \mathrm{L}$ and $02.73 \pm 0.63 \mathrm{mlU} / \mathrm{L}$ respectively. The study suggests that $\mathrm{FT}_{3}$ and $\mathrm{FT}_{4}$ gradually reduced from first trimester to third which showed that fetus and mother required more thyroid hormones.
\end{abstract}

Keywords: Thyroid hormone, Free $T_{3}$, Free $T_{4}$, Dehradun, trimester, pregnant women, fetus.

\section{Introduction}

Thyroid is a small endocrine gland found in the front of the neck. Thyroid hormones are essential for proper growth, proliferation, differentiation, apoptosis, development, neurotransmission, behavior and metabolic homeostasis (Karapanou and Papadimitriou, 2011). Thyroid gland generates the hormones thyroxine $\left(T_{4}\right)$, 3,5,3-triiodothyronine $\left(T_{3}\right)$, calcitonin and secretes them into the bloodstream. All thyroid hormone actions are mediated by the binding of 3,5,3-triiodothyronine $\left(T_{3}\right)$ to specific nuclear receptors and $T_{3}$ is the chief bioactive form of $T H$, whereas $T_{4}$ acts as a prohormone to $T_{3}$ (Karapanou and Papadimitriou, 2011).

Thyroid disorders are commonly divided into two main categories, hyperthyroidism and hypothyroidism. In hyperthyroidism, tissue is exposed to excessive amounts of circulating thyroid hormone. The most common cause of this syndrome is Graves' disease, followed by toxic multinodular goitre and solitary hyperfunctioning nodules. Autoimmune postpartum and subacute thyroiditis, tumors that secrete thyrotropin and drug-induced thyroid dysfunction are also important causes (Sharma et al., 2011). Hyperthyroidism in pregnant women is low but untreated overt hyperthyroidism are at increased risk for spontaneous miscarriage, fetal growth restriction, congestive heart failure, thyroid storm, preterm birth, pre-eclampsia, increased perinatal morbidity and mortality (Davis et al., 1989; Kriplani et al., 1994; Chang and Pearce, 2013). Hypothyroidism is a condition in which the thyroid gland does not produce enough amounts of the thyroid hormones-thyroxine $\left(T_{4}\right)$ and triiodothyronine $\left(T_{3}\right)$.
Hypothyroidism is related with a broad spectrum of reproductive disorders. Hypothyroidism is related with a broad spectrum of reproductive disorders ranging from abnormal sexual development through menstrual irregularities to infertility. The impact of hypothyroidism on the menstrual cycle has been identified since the 1950s (Goldsmith et al., 1952; Benson and Dailey, 1955). Wang and Crapo (1997) mentioned an abnormal thyroid-stimulating hormone level and $5 \%$ of women have overt hypothyroidism or hyperthyroidism. Low secretion of thyroid reduces growth of pregnant woman and her fetus as well as the child's neuropsychological development is adversely affected (Haddow et al., 1999; Pop et al., 1999). Joshi et al. (1993) investigated 178 women of menstrual and reproductive history and reported $31.8 \%$ of hypothyroid and $35.3 \%$ of hyperthyroid women had normal menstrual pattern in contrast with $56.3 \%$ of Euthyroid and $87.8 \%$ of healthy controls $(p<0.001)$. Literature suggests that no detailed investigation on thyroid hormones of pregnant women at Dehradun city. Therefore, this study was carried out to investigate thyroid hormone $\mathrm{TSH}$, Free $\mathrm{T}_{3}$ $\left(\mathrm{FT}_{3}\right)$ and Free $\mathrm{T}_{4}\left(\mathrm{FT}_{4}\right)$ status in pregnant women at Dehradun, Uttarakhand (India) during first, second and third trimester of pregnancy.

\section{Materials and methods}

Study population: This study comprises 100 pregnant women at Dehradun with age ranging from 20-35 years, visiting Doon (PG) Paramedical College, Dehradun, Uttarakhand (India). These cases were selected over a period of 3years (2010-13). 
Gestational age was calculated from the first day of the last normal menstrual period and gestational age $<14$, 14-27 and >28 weeks comprised the first, second and third trimesters of pregnancy (Mehran et al., 2013).

Collection of blood: Venous blood $(5 \mathrm{~mL})$ of pregnant women was collected in fasting state. Serum was prepared within $60 \mathrm{~min}$ of blood collection. Serum was store at $-20^{\circ} \mathrm{C}$ till get analyzed for thyroid function test. These samples were analyzed within $24 \mathrm{~h}$ from blood collection time.

Hormone analysis: Thyroid stimulating hormone (TSH), Serum free 3,5,3'-triiodothyronine $\left(\mathrm{FT}_{3}\right)$ and free 3,5,3',5'-tetraiodothyronine $\left(\mathrm{FT}_{4}\right)$ were analyzed using ERBA THYROKIT. Measurement of Free $\mathrm{T}_{3}\left(\mathrm{FT}_{3}\right)$ and Free $\mathrm{T}_{4}\left(\mathrm{FT}_{4}\right)$ was based on a direct, labeled antibody, competitive immunoassay, but TSH assay is based on one step immunoenzymatic sandwich principle in conjunction with biotin-streptavidin technology.

Statistical analysis: Data were represented as percentile, mean and standard deviation.

\section{Results and discussion}

About 107 pregnant women had visited in all trimester. But we analyzed only 100 pregnant women for present study. Pregnant women around 7\% were excluded because of pre-existing thyroid disorder. When compared with $\mathrm{FT}_{3}, \mathrm{FT}_{4}$ and $\mathrm{TSH}$ in first trimester, second trimester and third trimester. It was noted that $\mathrm{FT}_{3}$ concentration reduced by 54.73 and $39.36 \%$ respectively in the $2^{\text {nd }}$ and $3^{\text {rd }}$ trimesters as compared to first trimester. $\mathrm{FT}_{4}$ concentration also reduced by 84.65 and $56.05 \%$ in $2^{\text {nd }}$ and $3^{\text {rd }}$ trimesters as compared to first trimester. TSH concentration increased by 110.64 and $193.62 \%$ in $2^{\text {nd }}$ and $3^{\text {rd }}$ trimesters as compared to first trimester (Fig. 1). $\mathrm{FT}_{3}$ showed 5.81 and $1.71 \mathrm{pmol} / \mathrm{L}$ in $5^{\text {th }}$ percentile of first and third trimesters respectively. $\mathrm{FT}_{4}$ showed 11.43 and $5.18 \mathrm{pmol} / \mathrm{L}$ in $5^{\text {th }}$ percentile of first and third trimesters respectively. TSH showed 0.20 and $1.87 \mathrm{mIU} / \mathrm{L}$ in $5^{\text {th }}$ percentile of first and third trimesters respectively (Table 1 ).

This study provides trimester specific reference ranges for $\mathrm{FT}_{3}, \mathrm{FT}_{4}$ and $\mathrm{TSH}$ among pregnant women in Dehradun, Uttarakhand (India). Each trimester showed variations. The reference intervals for the healthy adults were 2.56-6.36 pmol/L for $\mathrm{FT}_{3}, 11.24-26.86 \mathrm{pmol} / \mathrm{L}$ for $\mathrm{FT}_{4}$ and 0.17-4.23 $\mathrm{mIU} / \mathrm{L}$ for TSH (Hubl et al., 2002). In first trimester, most pregnant women showed more $\mathrm{FT}_{3}$ as compared to reference but gradually reduced in second and third trimesters. $5^{\text {th }}$ percentile in $3^{\text {rd }}$ trimester was low in limit as compared to references. Similar observation was observed in $\mathrm{FT}_{4}$ of $3^{\text {rd }}$ trimester where mean value was $7.96 \pm 1.78$. This $\mathrm{FT}_{4}$ values was very low as compared to reference. TSH levels were maintained in all three trimesters.
Fig. 1. $\mathrm{FT}_{3}, \mathrm{FT}_{4}$ and $\mathrm{TSH}$ levels in pregnant women during various trimesters.

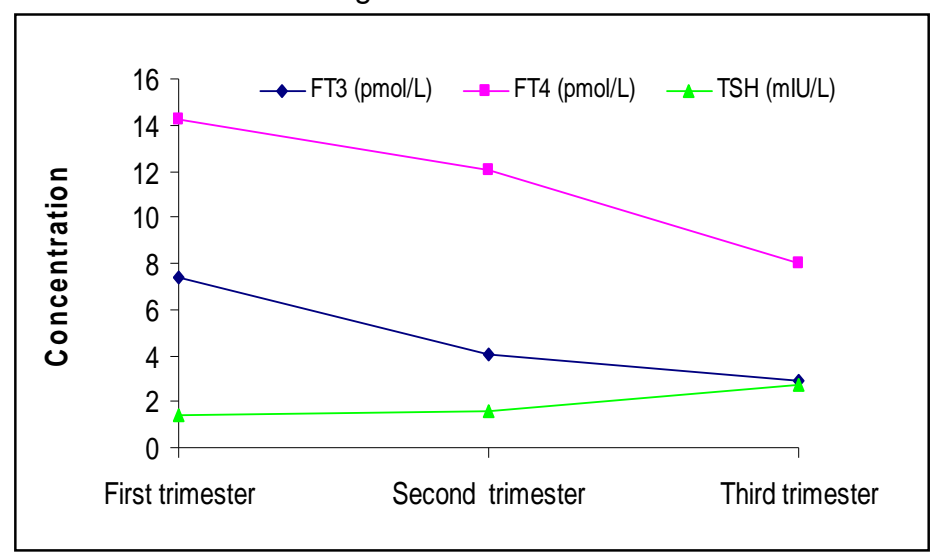

Table 1. Gestation specific percentile values of $\mathrm{FT}_{3}, \mathrm{FT}_{4}$ and TSH of pregnant women $(n=100)$.

\begin{tabular}{|c|c|c|c|c|}
\hline \multirow{2}{*}{$\begin{array}{c}\text { Trimester/thyroid } \\
\text { hormones }\end{array}$} & \multicolumn{3}{|c|}{ Percentile } & \multirow{2}{*}{$\begin{array}{c}\text { Mean } \\
\text { value } \pm \text { SD }\end{array}$} \\
\hline & $5^{\text {th }}$ & $50^{\text {th }}$ & $95^{\text {th }}$ & \\
\hline \multicolumn{5}{|l|}{ First trimester } \\
\hline $\mathrm{FT}_{3}(\mathrm{pmol} / \mathrm{L})$ & 05.81 & 07.08 & 09.60 & $07.40 \pm 1.26$ \\
\hline $\mathrm{FT}_{4}(\mathrm{pmol} / \mathrm{L})$ & 11.43 & 13.89 & 16.96 & $14.20 \pm 1.75$ \\
\hline TSH (mIU/L) & 00.20 & 01.35 & 02.97 & $01.41 \pm 0.93$ \\
\hline \multicolumn{5}{|l|}{ Second trimester } \\
\hline $\mathrm{FT}_{3}(\mathrm{pmol} / \mathrm{L})$ & 02.60 & 03.84 & 05.97 & $04.05 \pm 1.13$ \\
\hline $\mathrm{FT}_{4}(\mathrm{pmol} / \mathrm{L})$ & 09.22 & 11.56 & 15.50 & $12.02 \pm 2.01$ \\
\hline $\mathrm{TSH}(\mathrm{mIU} / \mathrm{L})$ & 00.39 & 01.43 & 02.93 & $01.56 \pm 0.86$ \\
\hline \multicolumn{5}{|l|}{ Third trimester } \\
\hline $\mathrm{FT}_{3}(\mathrm{pmol} / \mathrm{L})$ & 01.71 & 02.85 & 04.44 & $02.92 \pm 0.93$ \\
\hline $\mathrm{FT}_{4}(\mathrm{pmol} / \mathrm{L})$ & 05.18 & 08.06 & 10.52 & $07.96 \pm 1.78$ \\
\hline $\mathrm{TSH}(\mathrm{mlU} / \mathrm{L})$ & 01.87 & 02.69 & 03.70 & $02.73 \pm 0.63$ \\
\hline
\end{tabular}

Reduction in $\mathrm{FT}_{3}$ and $\mathrm{FT}_{4}$ concentrations clearly indicated that pregnant lady and fetus required more $\mathrm{T}_{3}$ and $\mathrm{T}_{4}$ hormones. Similarly, Bocos-Terraz et al. (2009) reported TSH values $(\mu \mathrm{lU} / \mathrm{mL}): 1.12 \pm 0.69$ ( $<10$ weeks), $1.05 \pm 0.67$ (11-20 weeks), $1.19 \pm 0.60$ (21-30 weeks), $1.38 \pm 0.76$ (31-36 weeks) and $1.46 \pm 0.72$ ( $>36$ weeks) in his study. Similarly Marwaha et al. (2008) mentioned $\mathrm{FT}_{3}$ of third trimester ranged from 3.3-5.18 pmol $/ \mathrm{L}$ which was slightly higher as compared to our finding. Kurioka et al. (2005) studied of 522 pregnant women from Japan and showed significant decrease in both $\mathrm{FT}_{3}$ and $\mathrm{FT}_{4}$ and increase in TSH with advancing pregnancy.

\section{Conclusion}

Present study is concerned only on pregnant women at Dehradun city and our study suggest that $\mathrm{FT}_{3}$ and $\mathrm{FT}_{4}$ gradually reduced from first trimester to third which showed that fetus and mother required more thyroid hormones. Thyriod stimulating hormones (TSH) was constant. Authors find that over all free thyroid level was less as compared to non-pregnant women. Further, authors suggest taking more iron, iodine to maintain free thyroid level. 


\section{References}

1. Benson, R.C. and Dailey, M.E. 1955. The menstrual pattern in hyperthyroidism and subsequent posttherapy hypothyroidism. Surgery Gynecol. Obstetr. 100: 19-26.

2. Bocos-Terraz, J.P., Izquierdo-Álvarez, S., Luís Bancalero-Flores, J., Álvarez-Lahuerta, R., Aznar Sauca, A., Real-López, E., Ibáñez-Marco, R., Bocanegra-García, V. and Rivera-Sánchez, G. (2009). Thyroid hormones according to gestational age in pregnant Spanish women. B.M.C. Res. Notes. 2: 237.

3. Chang, D.L.F. and Pearce, E.N. 2013. Screening for maternal thyroid dysfunction in pregnancy: A review of the clinical evidence and current guidelines. J. Thyroid Res. http://dx.doi.org/10.1155/2013/851326.

4. Davis, L.E., Lucas, M.J., Hankins, G.D.V., Roark, M.L. and Cunningham, F.G. 1989. Thyrotoxicosis complicating pregnancy. Am. J. Obstetr. Gynecol. 160(1): 63-70.

5. Goldsmith, R.E., Sturgis, S.H., Lerman, J. and Stanbury, J.B. 1952. The menstrual pattern in thyroid disease. J. Cl. Endocrinol. Metabol. 12: 846-855.

6. Haddow, J.E., Palomaki, G.E., Allan, W.C., Williams, J.R., Knight, G.J., Gagnon, J., O'Heir, C.E., Mitchell, M.L., Hermos, R.J., Waisbren, S.E., Faix, J.D. and Klein, R.Z. 1999. Maternal thyroid deficiency during pregnancy and subsequent neuropsychological development of the child. N. Engl. J. Med. 341(8): 549-555.

7. Hubl, W., Schmieder, J., Gladrow, E. and Demant, T. 2002. Reference intervals for thyroid hormones on the architect analyser. Clin. Chem. Lab. Med. 40(2): 165-166.

8. Joshi, J.V., Bhandarkar, S.D., Chadha, M., Balaiah, D. and Shah, R. 1993. Menstrual iregularities and lactation failure may precede thyroid dysfunction or goitre. J. Postgrad. Med. 39(3): 137-141.
9. Karapanou, O. and Papadimitriou, A. 2011. Thyroid hormone transporters in the human. Hormones. 10(4): 270-279.

10. Kriplani, A., Buckshee, K., Bhargava, V.L., Takker, D. and Ammini, A.C. 1994. Maternal and perinatal outcome in thyrotoxicosis complicating. Eur. J. Obstetr. Gynecol. Reproduct. Biol. 54(3): 159-163.

11. Kurioka, H., Takahashi, K. and Miyazaki, K. 2005. Maternal thyroid function during pregnancy and puerperal period. Endocr. J. 52: 587-591.

12. Marwaha, R.K., Chopra, S., Gopalakrishnan, S., Sharma, B., Kanwar, R.S., Sastry, A. and Singh, S. 2008. Establishment of reference range for thyroid hormones in normal pregnant Indian women. Brit. J. Obstetr. Gynaecol. 115 (5): 602-606.

13. Mehran, L., Amouzegar, A., Delshad, H., Askari, S., Hedayati, M., Amirshekari, G. and Azizi, F. 2013. Trimester-specific reference ranges for thyroid hormones in Iranian pregnant women. J. Thyroid Res. http://dx.doi.org/10.1155/2013/651517

14.Pop, V.J., Kuijpens, J.L., Van Baar, A.L., Verkerk, G., Van Son, M.M., De Vijlder, J.J., Vulsma, T., Wiersinga, W.M., Drexhage, H.A. and Vader, H.L. 1999. Low maternal free thyroxine concentrations during early pregnancy are associated with impaired psychomotor development in infancy. Clin. Endocrinol. (Oxf). 50(2): 149-155.

15. Sharma, M., Aronow, W.S., Patel, L., Gandhi, K. and Desai, H. 2011. Hyperthyroidism. Med. Sci. Monit. 17(4): RA85-91.

16.Wang, C. and Crapo, L.M. 1997. The epidemiology of thyroid disease and implications for screening. Endocrinol. Metab. Clin. North Am. 26(1): 189-218. 